\title{
Parasites of veterinary importance from domestic animals in uMkhanyakude district of KwaZulu-Natal province
}

\begin{tabular}{|c|c|}
\hline \multicolumn{2}{|c|}{ 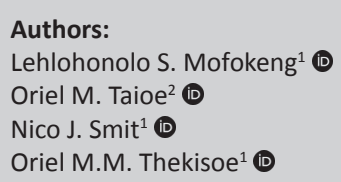 } \\
\hline \multicolumn{2}{|c|}{$\begin{array}{l}{ }^{1} \text { Unit for Environmental } \\
\text { Sciences and Management, } \\
\text { North-West University, } \\
\text { Potchefstroom, South Africa }\end{array}$} \\
\hline \multicolumn{2}{|c|}{$\begin{array}{l}{ }^{2} \text { National Zoological Garden, } \\
\text { South African National } \\
\text { Biodiversity Institute, } \\
\text { Pretoria, South Africa }\end{array}$} \\
\hline \multicolumn{2}{|c|}{$\begin{array}{l}\text { Corresponding author: } \\
\text { Oriel Thekisoe, } \\
\text { oriel.thekisoe@nwu.ac.za }\end{array}$} \\
\hline \multicolumn{2}{|c|}{$\begin{array}{l}\text { Dates: } \\
\text { Received: } 19 \text { Sept. } 2019 \\
\text { Accepted: } 19 \text { Feb. } 2020 \\
\text { Published: } 13 \text { July } 2020\end{array}$} \\
\hline \multicolumn{2}{|c|}{$\begin{array}{l}\text { How to cite this article: } \\
\text { Mofokeng, L.S., Taioe, O.M., } \\
\text { Smit, N.J. \& Thekisoe, } \\
\text { O.M.M., 2020, 'Parasites of } \\
\text { veterinary importance from } \\
\text { domestic animals in } \\
\text { uMkhanyakude district of } \\
\text { KwaZulu-Natal province', } \\
\text { Journal of the South African } \\
\text { Veterinary Association } 91(0) \text {, } \\
\text { a2023. https://doi.org/ } \\
\text { 10.4102/jsava.v91i0.2023 }\end{array}$} \\
\hline \multicolumn{2}{|c|}{$\begin{array}{l}\text { Copyright: } \\
\text { (c) 2020. The Authors. } \\
\text { Licensee: AOSIS. This w } \\
\text { is licensed under the } \\
\text { Creative Commons } \\
\text { Attribution License. }\end{array}$} \\
\hline \multicolumn{2}{|l|}{ Read online: } \\
\hline 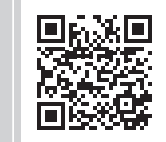 & $\begin{array}{l}\text { Scan this QR } \\
\text { code with your } \\
\text { smart phone or } \\
\text { mobile device } \\
\text { to read online. }\end{array}$ \\
\hline
\end{tabular}

This study investigated the occurrence and phylogenetic relationship of protozoan parasites and Ehrlichia infecting domestic animals from three municipalities in uMkhanyakude district of KwaZulu-Natal province, South Africa. A total of 208 blood samples collected from clinically healthy cattle, sheep, goats and dogs from uMkhanyakude district were examined by polymerase chain reaction (PCR) assays, using either genus or species-specific primers to determine the occurrence and phylogenetic relationship of various protozoan parasites and Ehrlichia of veterinary importance. A total of 5/109 (4.6\%) cattle were PCR-positive for the presence of Toxoplasma gondii, 33/109 (30.3\%) for Babesia bovis, 24/109 (22.02\%) for Babesia bigemina and 20/109 (18.3\%) for Trypanosoma sp., while 3/10 (30\%) of sheep were PCR-positive for Theileria ovis and none of the goats were positive for any of the detected pathogens. The co-infection of 4/109 (3.7\%) B. bovis and B. bigemina was detected in cattle. Only Ehrlichia canis was detected in dogs with infection rate of 20/48 (41.7\%). Sequences of PCR-positive isolates (B. bovis, B. bigemina, E. canis, T. ovis and T. gondii) showed that they were closely related to their relevant species from various countries. These findings have expanded our knowledge about the prevalence and phylogenetic similarity between protozoan parasites and Ehrlichia isolates of South African origin. To date, this is the first study in South Africa to detect T. gondii infections from cattle blood using PCR.

Keywords: Babesia sp.; Ehrlichia canis; Theileria sp.; Trypanosoma sp.; Toxoplasma gondii.

\section{Introduction}

Protozoan and ehrlichial diseases are significant constraints to the production of livestock in sub-Saharan Africa. In South Africa, around 18\% of livestock mortalities are because of protozoan diseases (Mtshali \& Mtshali 2013). These diseases have substantial impact on the country's economic security and poor communities who are dependent on livestock production, as they lead to losses of meat, wool, milk and manure (Perry \& Sones 2007; Ringo et al. 2018). In sub-Saharan Africa, little information is available on their presence and distribution. Normally, protozoan parasite infection is thought to result from a complex interaction between pathogens, vectors, vertebrate host and the environment (Weny et al. 2017). Piroplasmosis, trypanosomosis, ehrlichiosis, hepatozoonosis and toxoplasmosis are among parasitic diseases that cause significant threat to the health of domestic animals. Various piroplasm species such as Babesia bovis, Babesia bigemina, Babesia ovis, Babesia motasi, Babesia rossi, Babesia vogelli, Theileria ovis, Theileria lestoquardi, Theileria seperata and Theileria parva have been described in small ruminants. These species are known to be causative agents of babesiosis and theileriosis, respectively (Ijaz et al. 2013; Mohammadi et al. 2017). In southern Africa, B. bovis and B. bigemina are two economically important species infecting cattle and have high prevalence in tropical and subtropical regions (Mtshali \& Mtshali 2013), while B. ovis is known to be highly pathogenic in sheep with a mortality ranges of 30\% - 50\% (Ijaz et al. 2013; Ringo et al. 2018). Two species of canine Babesia, B. rossi and B. vogelli, are known to be endemic to South Africa (Matjila et al. 2004). The clinical signs of $B$. vogelli have not yet been estimated and this led to B. rossi being considered as the most prevalent species in South Africa as it causes severe, often fatal disease (Jacobson 2006).

The most pathogenic member Theileria, particularly in sheep, is known to be T. lestoquardi, while T. ovis is reported to be less pathogenic and usually causes subclinical infection albeit animals subjected to stress may develop significant illness (Durrani et al. 2011). On the contrary, T. seperata is regarded as non-pathogenic but can be fatal to immunocompromised animals or those that are newly introduced to endemic areas (Luo \& Yin 1997; Ringo et al. 2018). Following the eradication of 
East coast fever, Corridor disease emerged as the most significant form of theileriosis in South African cattle. In areas where common grazing among cattle and infected buffalo occur and where there is an abundance of tick vector species (Rhipicephalus appendiculatus and Rhipicephalus zambeziensis), the disease still poses a serious threat (Uilenberg 1999).

Among the causal agents of chronic, debilitating, emaciating and usually fatal disease in domestic animals, Trypanosoma infections are major causative agents of alopecia, emaciation, lymphadenopathy and anaemia in domesticated animals (World Organization Of animal Health [OIE] 2013). However, the outcome of the infection varies among trypanosome species, livestock species and the virulence of the strains (Connor \& Van den Bossche 2004). Trypanosoma vivax, Trypanosoma simiae, Trypanosoma uniforme, Trypanosoma brucei brucei and Trypanosoma congolense are important causative agents of animal African trypanosomosis, also known as nagana in Africa, with tsetse flies acting as biological vectors for the cyclic transmission of the disease in domesticated animals (Steverding 2008). This is attributed to their pathogenicity and effects on productivity (Trail et al. 1994; Wellde et al. 1989).

Toxoplasma gondii is a widespread global zoonotic protozoan parasite that infects a wide range of warm-blooded animals (Howe \& Sibley 1995). Humans and animals acquire infection through ingestion of raw and undercooked infected meat that contains viable Toxoplasma tissue cyst or food and drink contaminated with Toxoplasma oocysts excreted from the faeces of infected felids. This makes toxoplasmosis the most important foodborne and waterborne parasitic disease (Bowie et al. 1997; Torgerson et al. 2015). Most animals infected with toxoplasmosis show no clinical manifestation of the disease, but the disease is known to be the leading cause of abortion in sheep.

Ehrlichia canis and Hepatozoon canis are causative agents of canine monocytic ehrlichiosis and canine hepatozoonosis, respectively. The main vector of both pathogens is the brown dog tick, Rhipicephalus sanguineus. Diseases caused by these pathogens occur worldwide and are among the most commonly reported diseases in dogs (Taques et al. 2016; Vieira et al. 2011). Unlike E. canis and other tick-transmitted diseases, ingestion of infected ticks by dogs is the main route of transmission of Hepatozoon rather than through the feeding of the tick on the host. However, alternative routes have been suggested and reported for both pathogens (Aguiar et al. 2007; Ewing \& Panciera 2003). Both ehrlichiosis and hepatozoonosis are manifested by a variety of clinical signs that may include, among others, fever, haemophilia, bone marrow failure and death in irreversible cases (Gondim et al. 1998; Mundim et al. 1994).

It is documented that the occurrence of these pathogens hinders the development of livestock sector, which contributes about $49 \%$ of agricultural output in South Africa (Terkawi et al. 2011). Furthermore, it is currently unknown whether South African domestic dogs carry zoonotic tick-borne pathogens (TBPs). Therefore, considering dogs as pets and the significance of livestock production in the South African economic landscape, in this study, we determined the occurrence and phylogenetic relationship of parasitic protozoan parasites and Ehrlichia infecting domestic animals in north-eastern KwaZulu-Natal (KZN).

\section{Material and methods Blood samples}

Blood samples were collected from healthy cattle, sheep, goats and dogs in three local municipalities, namely, Mtubatuba, Big 5 Hlabisa and UmHlabuyalingana of the uMkhanyakude district $\left(28^{\circ} 01^{\prime} 25^{\prime \prime} 9 \mathrm{~S}, 32^{\circ} 17^{\prime} 30^{\prime \prime} 30 \mathrm{E}\right), \mathrm{KZN}$ province, South Africa (Figure 1). A total of 208 blood samples were obtained from cattle $(n=109)$, sheep $(n=10)$, goats $(n=40)$ and dogs $(n=49)$. In these municipalities, rural communal farming is predominately practised and forms the main source of income in some households in the area. The owners of the sampled animals did not have any information about the age of the animals nor knowledge on the type of breed for goats and sheep. The cattle breed is Nguni. Sheep are not desired as domestic animals in this province because of cultural beliefs, and hence, only few were available during the sampling period.

\section{Molecular detection of parasitic protozoa and Ehrlichia}

Genomic deoxyribonucleic acid (DNA) was extracted using the salting out method adopted from Nasiri et al. (2005) with few modifications. Polymerase chain reaction was used to screen all the samples with genus or species-specific primers obtained from previous studies (Table 1). For each PCR assay, $2 \mu \mathrm{L}$ of the extracted genomic DNA was added into a $25-\mu \mathrm{L}$ reaction mixture containing $2.5 \mu \mathrm{L}$ of $10 \times$ standard Taq Reaction Buffer, $0.5 \mu \mathrm{L}$ of forward and reverse primer $(10 \mu \mathrm{M}), 0.5 \mu \mathrm{L}$ of $10 \mathrm{mM}$ Deoxynucleotide triphosphates (dNTPs), $0.125 \mu \mathrm{L}$ of Taq DNA polymerase and double distilled water (DDW) to a final volume to $25 \mu \mathrm{L}$. The reactions were run on a proFlex thermocycler (Applied Biosystems, California, United States [US]) using the following thermocycling conditions: initial denaturation at $95^{\circ} \mathrm{C}$ for 30 seconds, followed by 35 cycles of denaturation at $95^{\circ} \mathrm{C}$ for $30 \mathrm{~s}$. This was followed by annealing temperature (Table 1 ) for 1 minute, extension at $68^{\circ} \mathrm{C}$ for $1 \mathrm{~min}$ and final extension at $68{ }^{\circ} \mathrm{C}$ for $5 \mathrm{~min}$. Double distilled water was used as a negative control. Synthesised genomic DNA of T. gondii and canine Babesia referred to as g-block (Whitehead scientific-Integrated DNA Technologies, Johannesburg, South Africa) were used as positive controls for Toxoplasma and canine Babesia, respectively. The genomic DNA of T. congolense IL3000, T. b. brucei GuTat1.3 and T. theileri Japan Isolate was used as positive control for Trypanosoma species. The genomic DNA of B. bigemina South African strain, B. bovis SA strain obtained from North-West university, were used as positive control for bovine Babesia. The genomic DNA of T. parva provided by the North-West University was used as positive control for bovine Theileria. Following 


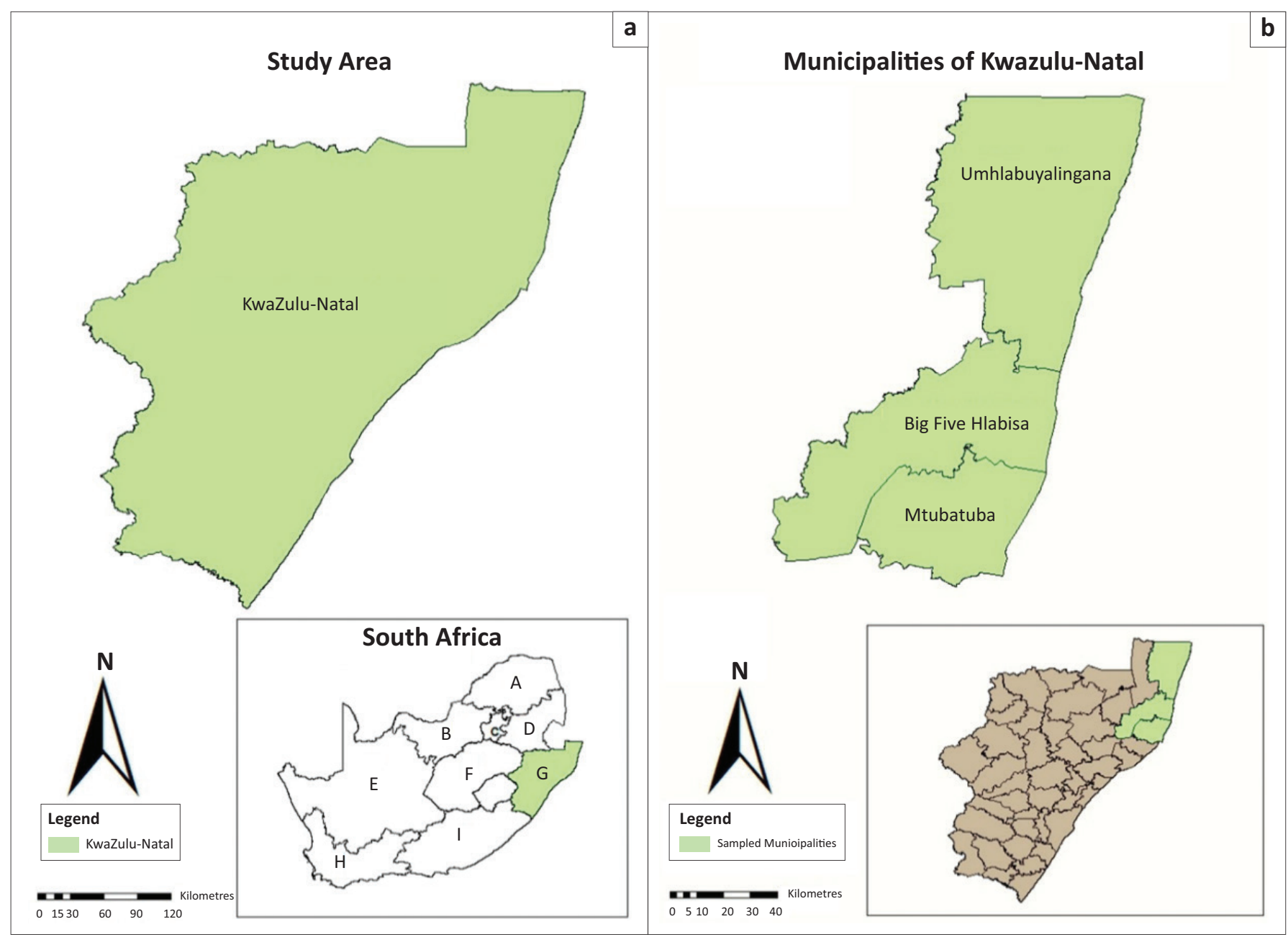

FIGURE 1: Map showing the sampled area. (a) KwaZulu-Natal province which is designated as G with the South African provincial map. (b) uMkhanyakude district with its three local municipalities that are in the northeastern part of KwaZulu-Natal province.

TABLE 1: Sequences of primers used for polymerase chain reaction amplification of protozoan parasites and Ehrlichia canis.

\begin{tabular}{|c|c|c|c|c|c|c|}
\hline Species & Assay & Primer sequence $\left(5^{\prime}-3^{\prime}\right)$ & $\begin{array}{l}\text { Annealing } \\
\left({ }^{\circ} \mathrm{C}\right)\end{array}$ & Product size & Target gene & Reference \\
\hline B. bovis & PCR & $\begin{array}{l}\text { CACGAGGAAGGAACTACCGATGTTGA } \\
\text { CCAAGGAGCTTCAACGTACGAGGTCA }\end{array}$ & 55 & $360 \mathrm{bp}$ & $R A P-1$ & Mtshali and Mtshali (2013) \\
\hline B. bovis & $\mathrm{nPCR}$ & $\begin{array}{l}\text { TCAACAAGGTACTCTATATGGCTACC } \\
\text { CTACCGAGCAGAACCTTCTTCACCAT }\end{array}$ & 55 & 298 bp & & Mtshali and Mtshali (2013) \\
\hline B. bigemina & PCR & $\begin{array}{l}\text { СATCTAATTTCTCTCCATACCCCTCC } \\
\text { CCTCGGCTTCAACTCTGATGCCAAAG }\end{array}$ & 55 & $278 \mathrm{bp}$ & Spel-Aval & Mtshali and Mtshali (2013) \\
\hline B. bigemina & $\mathrm{nPCR}$ & $\begin{array}{l}\text { CGCAAGCCCAGCACGCCCCGGTGC } \\
\text { CCGACCTGGATAGGCTGTGTGATG }\end{array}$ & 55 & $170 \mathrm{bp}$ & & Mtshali and Mtshali (2013) \\
\hline T. parva & PCR & $\begin{array}{l}\text { ATG ACA AAC ACA GAA GTC GCC CT ATT TCA TCC } \\
\text { TTC TTC TTG ATT GCG T }\end{array}$ & 53 & $1101 \mathrm{bp}$ & $18 S$ SSU rRNA & Mans et al. (2011) \\
\hline Trypanosoma sp. & PCR & GCG TTC AAA GAT TGG GCA AT CGC CCG AAA GTT CAC C & 58 & $300 \mathrm{bp}-800 \mathrm{bp}$ & & Desquesnes and Davila (2002) \\
\hline Babesia/Theileria sp. & PCR & $\begin{array}{l}\text { CAC AGG GAG GTA GTG ACA AG AAG AAT TTC } \\
\text { ACC TAT GAC AG }\end{array}$ & 58 & $389 b p-430 b p$ & 18S rRNA & $\begin{array}{l}\text { Shayan, Hooshmand and } \\
\text { Rabhari (2008) }\end{array}$ \\
\hline B. ovis & $\mathrm{nPCR}$ & $\begin{array}{l}\text { GTC TGC GCG CGG CCT TTG CG CAC AGG GAG GTA } \\
\text { GTG ACA AG }\end{array}$ & 58 & $186 \mathrm{bp}$ & 18S rRNA & Shayan et al. (2008) \\
\hline B. motasi & $\mathrm{nPCR}$ & CGC GAT TCC GTT ATT GGA G CAC AGG GAG GTA GTG ACA AG & 58 & 205 bp & $18 \mathrm{~S}$ rRNA & Shayan et al. (2008) \\
\hline T. gondii & $\mathrm{nPCR}$ & $\begin{array}{l}\text { GGC GAC CAA TCT GCG AAT ACA CC TGC ATA GGT } \\
\text { TGC AGT CAC TG }\end{array}$ & 57 & $194 \mathrm{bp}$ & & Burg et al. (1989) \\
\hline B. rossi & PCR & $\begin{array}{l}\text { GTG AAC CTT ATC ACT TAA AGG AGG AGT TGC TTA CGC } \\
\text { ACT CA }\end{array}$ & 50 & 342 bp & 18S rRNA & Duarte et al. (2008) \\
\hline B. vogeli & PCR & GTG AAC CTT ATC ACT TAA AGG CAA CTC CTC CAC GCA ATC G & 50 & $590 \mathrm{bp}$ & $18 \mathrm{~S}$ rRNA & Duarte et al. (2008) \\
\hline E. canis & PCR & $\begin{array}{l}\text { TCG CTA TTA GAT GAG CCT ACG T GAG TCT GGA CCG } \\
\text { TAT CTC AGT }\end{array}$ & 60 & $154 \mathrm{bp}$ & $16 \mathrm{~S}$ rRNA & Peleg et al. (2010) \\
\hline H. canis & PCR & ATA CAT GAG CAA AAT CTC AAC CTT ATT CCA TGC TGC AG & 57 & $625 \mathrm{bp}$ & 18S rRNA & Rubuni et al. (2005) \\
\hline
\end{tabular}

bp, base pair; rRNA, ribosomal ribonucleic acid; B. bovis, Babesia bovis; B. bigemina, Babesia bigemina; B. ovis, Babesia ovis; B. motasi, Babesia motasi; T. ovis, Theileria ovis; T. gondii, Toxoplasma gondii; E. canis, Ehrlichia canis; H. canis Hepatozoon canis; B. vogeli, Babesia vogeli; B. rossi, Babesia rossi; PCR, polymerase chain reaction. 
the amplification, $5 \mu \mathrm{L}$ amplicon was analysed by electrophoresis using 1\% agarose gel stained with ethidium bromide and visualised under ultraviolet (UV) light. For nested PCR, $1 \mu \mathrm{L}$ of the primary PCR products was added into a second PCR mixture containing the same reagent composition as described above, except that the nested PCR primers were used instead of the external primers. Reaction mixtures were run as described above.

\section{Sequence alignment and phylogenetic analysis}

The PCR-generated fragments were sent to Inqaba Biotechnical Industries (Applied Biosystem, Johannesburg) for purification and direct sequencing in both directions. One to three individually amplified DNA fragments of each selected sample were sequenced. The obtained sequences were compared with similar sequences of the same pathogens from other regions of the world in GenBank. Deoxyribonucleic acid sequences were edited, aligned with Clustal W and visually checked in MEGA 7.0. The genetic distance ( $p$-distance) of the sequences between taxa was also calculated using MEGA version 7.0. Phylogenetic analysis was performed using maximum likelihood method with 1000 bootstrap replicates to estimate the robustness of individual branches (Mtshali \& Mtshali 2013).

\section{Statistical analysis}

The proportions for $95 \%$ confidence intervals (95\% CIs) were computed as CIs for proportions with binomial data using no continuity correction (Mtshali et al. 2013). This was calculated by hand using $P=Z\left(\frac{1-p}{n}\right)$.

\section{Ethical considerations}

This study was approved by the Scientific committee of the Integrated Pest Management of North-West University as a no risk study (project number NWU-IPM-2017-003).

\section{Results}

\section{Overall infection rate}

A total of 208 domestic animals were sampled in this study and were screened for T. ovis, Babesia sp., Trypanosoma sp., T. gondii,
H. canis and E. canis. The T. ovis had an overall prevalence of $6.0 \%(95 \% \mathrm{CI}= \pm 6.58)$, Trypanosoma sp. 9.6\% (95\% CI = \pm 4.00$)$, T. gondii $2.4 \%(95 \% \mathrm{CI}= \pm 2.08)$, B. bovis $30.3 \%( \pm 8.60)$, B. bigemina $22.02 \%( \pm 7.46)$ and $E$. canis $40.8 \%(95 \% \mathrm{CI}= \pm 13.72)$. One set of mixed infection was detected in this study, and B. bigemina and $B$. bovis were detected with an overall rate of $3.7 \%( \pm 3.53)$. Babesia ovis, B. rossi, B. vogelli, $H$. canis and T. parva were not detected from their respective hosts.

\section{Infection rate based on hosts}

It was observed that $18.35 \%(95 \% \mathrm{CI}= \pm 7.45)$ cattle, $7.5 \%(95 \%$ $\mathrm{CI}= \pm 16.33)$ sheep, $0.0 \%(95 \% \mathrm{CI}= \pm 0.0)$ goats and $13.61 \% \mathrm{dogs}$ were positive for at least one pathogen (Table 2). In sheep, T. ovis was detected in 3/10 (30\%) $(95 \% \mathrm{CI}= \pm 28.42)$, and Trypanosoma sp., T. gondii and ovine Babesia sp. were not detected. On the contrary, in cattle, T. gondii was detected in $5 / 109$ which is $4.58 \%$ (95\% CI $= \pm 3.92)$ and Trypanosoma sp. (18.35\%). In dogs, no canine Babesia and Hepatozoon were detected, although E. canis was identified in $40.8 \%(95 \% \mathrm{CI}= \pm 13.72)$.

\section{Infection rate based on the local municipalities}

The highest occurrence of protozoan parasites and E. canis was recorded in Big 5 Hlabisa local municipality in which $30 \%(95 \% \mathrm{CI}= \pm 28.42), 9.4 \%(95 \% \mathrm{CI}= \pm 2.49), 12.64 \%$ $(95 \% \mathrm{CI}= \pm 7.81), 30 \%(95 \% \mathrm{CI}= \pm 27.17), 30.3 \%(95 \% \mathrm{CI}= \pm 10.92)$ and $6.19 \%(95 \% \mathrm{CI}= \pm 18.11)$ of animals were infected with T. ovis, T. gondii, Trypanosoma sp., E. canis, B. bovis and B. bigemina, respectively. The uMhlabauyalingana local municipality had the highest infection rate followed by Big 5 Hlabisa, while the lowest prevalence was observed in Mtubatuba local municipality (Table 3).

\section{Comparative analysis}

The BLASTn analysis of the partial sequence of RAP-1 genomic region (320 base pairs [bp]) of $B$. bovis obtained in this study (MN683993) matched with similar congeners from China (KT318580.1) and South Africa (KC894392) with high bootstrap support. The other sequence from this study (MN683992) showed $99.0 \%$ nucleotide identity with the above-mentioned strains. The T. ovis partial sequences (MK643268 and MK643269) of $18 \mathrm{~S}$ ribosomal ribonucleic acid (rRNA) gene

TABLE 2: Overall infection rate of protozoan parasites and Ehrlichia from different hosts.

\begin{tabular}{|c|c|c|c|c|c|c|c|c|c|}
\hline Host & Total samples & Trypanosoma sp. & B. bovis & B. bigemina & B. ovis & B. motasi & T. ovis & T. gondii & E. canis \\
\hline Cattle & 109 & $18.35 \%( \pm 7.45)^{\dagger}$ & $30.3 \%( \pm 8.60)$ & $22.02 \%( \pm 7.46)$ & NS & NS & NS & $4.58 \%( \pm 3.92)$ & NS \\
\hline Sheep & 10 & $0.0 \%( \pm 0.0)$ & NS & NS & $0.0 \%( \pm 0.0)$ & $0.0 \%( \pm 0.0)$ & $30 \%( \pm 28.42)$ & $0.0 \%( \pm 0.0)$ & NS \\
\hline Goats & 40 & $0.0 \%( \pm 0.0)$ & NS & NS & $0.0 \%( \pm 0.0)$ & $0.0 \%( \pm 0.0)$ & $0.0 \%( \pm 0.0)$ & $0.0 \%( \pm 0.0)$ & NS \\
\hline Dogs & 49 & $0.0 \%( \pm 0.0)$ & NS & NS & NS & NS & NS & $0.0 \%( \pm 0.0)$ & $40.8 \%( \pm 13.72)$ \\
\hline
\end{tabular}

NS, not screened.; B. bovis, Babesia bovis; B. bigemina, Babesia bigemina; B. ovis, Babesia ovis; B. motasi, Babesia motasi; T. ovis, Theileria ovis; T. gondii, Toxoplasma gondii; E. canis, Ehrlichia canis. $\dagger, 95 \%$ confidence intervals.

TABLE 3: Infection rate of parasites from different municipalities.

\begin{tabular}{|c|c|c|c|c|c|c|c|}
\hline Municipalities & Total samples & Trypanosoma sp. (\%) & Babesia bigemina (\%) & Babesia bovis (\%) & Theileria ovis & Toxoplasma gondii (\%) & Ehrlichia canis (\%) \\
\hline Big 5 hlabisa & 129 & 12.64 & 6.19 & 30.3 & 30 & 5.38 & 30 \\
\hline uMhlabauyalingana & 48 & 12.5 & 3.75 & 0.0 & 0.0 & 0.0 & 55.6 \\
\hline Mtubatuba & 31 & 0.0 & 6.25 & 0.0 & 0.0 & 0.0 & 36.3 \\
\hline
\end{tabular}


showed $98.4 \%$ nucleotide identity with other homologous sequences (MN493111.1 and MF182656.1) extracted from GenBank. One B. bigemina SpeI-AvaI gene sequence obtained from this study matched with LK391707.1 from the United Kingdom with identity of $89.0 \%$ and coverage of $88.0 \%$ (Figure 1-A1). The BLASTn analysis of the B1 gene sequence of T. gondii (194 bp) obtained in this study showed $100 \%$ nucleotide identity with homologous sequence of T. gondii from China (MK521884.1) and Mexico (KX270388.1). The BLASTn alignment with one of the sequences is indicated in supplementary Figure 2-A1. The BLASTn analysis of the 16S rRNA gene sequence of E. canis (124 bp) obtained in this study showed $89 \%$ nucleotide identity with homologous sequence of E. canis from Nigeria (JQ976640.1) (Figure 3-A1).

\section{Phylogenetic analysis}

Retrieved sequences from the amplification of the Rap-1 gene for detection of $B$. bovis were deposited to GenBank under the accession numbers MN683992 and MN683993. Subsequently, the maximum likelihood tree revealed three major clades

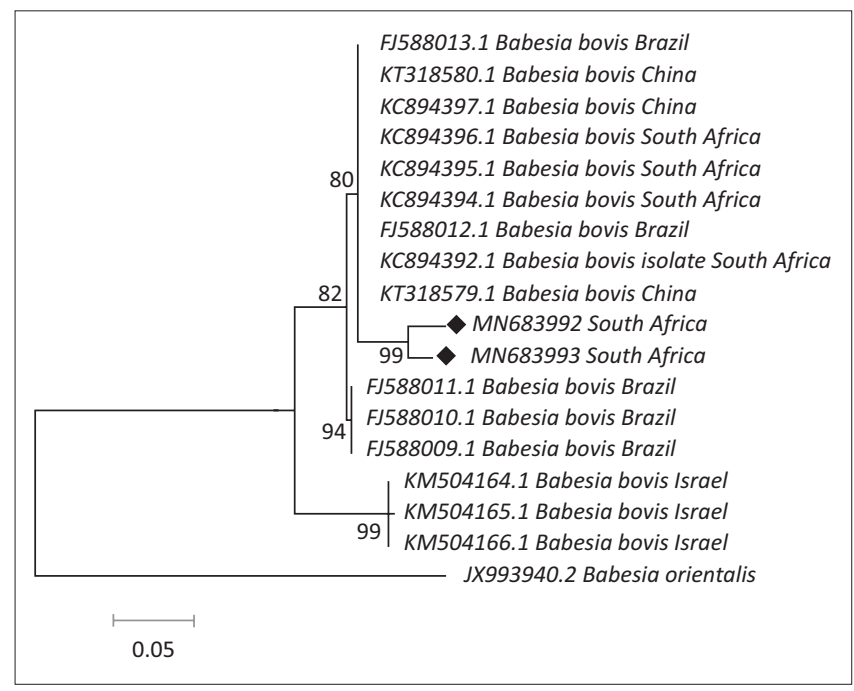

Source: Kumar, S., Stecher G. \& Tamura, K., 2016, 'MEGA7: molecular evolutionary genetics analysis version 7.0 for bigger datasets', Molecular biology and evolution 33(7), 1870-1874. FIGURE 2: In phylogenetic tree analysis of Babesia bovis based on RAP-1 gene, the tree was constructed with maximum likelihood method based on the Tamura-3-parameter model, with bootstrap values (expressed as percentages of 1000 replications) superimposed at branching points. The sequences produced in this study are shown with bullet points. The evolutionary distances were computed using the $p$-distance method. Babesia orientalis was used as an outgroup. with high bootstrap support values as well as divergence estimates ( $99 \%$ identical, $p=0.034$ ) with an average distance of $p=0.053$ (Figure 2 and Table 4). Sequences generated from this study (at 99\% bootstrap support) formed a sister clade with the South Africa, China and Brazil sequences at $80 \%$ bootstrap. When constructing the phylogenetic tree, the two T. ovis 18S rRNA sequences from this study (MK643269 and MK643268) clustered into a single clade with T. ovis sequences from various countries including South Africa with 100\% identity and average divergence between the species was $p=0.022$ (Figure 3 and Table 5).

\section{Discussion}

Protozoan and ehrlichial diseases are veterinary, medically and economically important contagious diseases affecting the domestic animals in sub-Saharan Africa, and hence, their prevalence and control is very important (Ademola \& Onyiche 2013; Ringo et al. 2018). In this study, a low prevalence of protozoan parasites was observed and this could be attributed to the low sample size. It could also be because of the improvement in husbandry systems, better veterinary care and climate change.

There is no epidemiological data on livestock toxoplasmosis in this study area and, to the best of our knowledge, this is the first study that has detected T. gondii in cattle blood by PCR in South Africa. Recent serological studies have also reported a seroprevalence of $16.9 \%, 10.1 \%$ and $13.81 \%$ in cattle using latex agglutination test, Microscopic agglutination test (MAT) and enzyme-linked immunosorbent assay (ELISA), respectively, in Nigeria (Joshua \& Akinwumi 2003; Okewole 2007; Onyiche \& Ademola 2015). The low prevalence of Toxoplasma in cattle in the present study could be because cattle are genetically resistant to $T$. gondii. However, its presence could be attributed to the fact that they are raised outdoors as grazing animals to meet their nutritional needs, and as a result, they have more contact with rodents and soil contaminated with oocyst (Onyiche \& Ademola 2015). Differences in the levels of infection with $T$. gondii between cattle in the different studies could possibly reflect variations in exposure rates to the parasite, which could be attributed to the contamination rate of the environment. No T. gondii DNAs were detected in the dog, goats or sheep samples, which contradicts reports from Ethiopia and Tunisia where T. gondii DNA was detected

TABLE 4: Evolutionary divergence of Babesia bovis representing 320 base pair region and expressed as pairwise distance ( $p$-distance) (bottom left) and standard error (top right).

\begin{tabular}{|c|c|c|c|c|c|c|c|c|c|c|}
\hline Accession number and Origin & 1 & 2 & 3 & 4 & 5 & 6 & 7 & 8 & 9 & 10 \\
\hline 1. MN683992 South Africa & - & 0.010 & 0.019 & 0.012 & 0.012 & 0.012 & 0.013 & 0.013 & 0.012 & 0.019 \\
\hline 2. MN683993 South Africa & 0.034 & - & 0.019 & 0.011 & 0.011 & 0.011 & 0.012 & 0.012 & 0.011 & 0.019 \\
\hline 3. KM504165.1 Israel & 0.147 & 0.135 & - & 0.016 & 0.016 & 0.016 & 0.016 & 0.016 & 0.016 & 0.003 \\
\hline 4. FJ588012.1 Brazil & 0.053 & 0.044 & 0.094 & - & 0.000 & 0.000 & 0.005 & 0.005 & 0.000 & 0.016 \\
\hline 5. KC894395.1 South Africa & 0.053 & 0.044 & 0.094 & 0.000 & - & 0.000 & 0.005 & 0.005 & 0.005 & 0.016 \\
\hline 6. KC894395.1 South Africa & 0.053 & 0.044 & 0.094 & 0.000 & 0.000 & - & 0.005 & 0.005 & 0.000 & 0.016 \\
\hline 7. FJ588010.1 Brazil & 0.063 & 0.053 & 0.091 & 0.009 & 0.009 & 0.009 & - & 0.000 & 0.005 & 0.015 \\
\hline 8. FJ588009.1 Brazil & 0.063 & 0.053 & 0.091 & 0.009 & 0.009 & 0.009 & 0.00 & - & 0.005 & 0.015 \\
\hline 9. КT318580.1 China & 0.053 & 0.044 & 0.094 & 0.000 & 0.000 & 0.000 & 0.009 & 0.009 & - & 0.016 \\
\hline 10. KM504164.1 Israel & 0.144 & 0.132 & 0.003 & 0.091 & 0.091 & 0.091 & 0.088 & 0.088 & 0.091 & - \\
\hline
\end{tabular}

Source: Kumar, S., Stecher G. \& Tamura, K., 2016, 'MEGA7: molecular evolutionary genetics analysis version 7.0 for bigger datasets', Molecular biology and evolution 33(7), $1870-1874$. 
in $45.45 \%$ and $1.8 \%$ of goats and sheep samples, respectively (Gebremedhin et al. 2014; Gharbi et al. 2013). There are various risk factors such as age, sex, breed and climate conditions which may have contributed to the differences in prevalence in this study and other studies across the world.

Little attention has been given to ovine piroplasmosis compared to bovine piroplasmosis despite its widespread distribution through tropical and subtropical areas. According to Berggoetz et al. (2014), theileriosis in small ruminants can be caused by a number of well-known species such as T. ovis, T. seperata and T. lestoquardi. In this study, T. ovis was the only species detected (6.0\%). However, previous studies in South Africa have reported T. ovis with a

\begin{tabular}{|l|l|}
\hline MG203886.1 Theileria ovis South Africa \\
MK643269.1 Theileria ovis South Africa \\
MJ603460.1 Theileria ovis China \\
KC599236.1 Theileria ovis Iran \\
KR094863.1 Theileria ovis isolate DRC \\
KR094867.1 Theileria ovis isolate DRC \\
AY260171.1 Theileria ovis Sudan \\
AY260174.1 Theileria cf. ovis Tanzania \\
GU726901.1 Theileria ovis Italy \\
JQ737135.1 Theileria ovis Iran \\
KT851433.1 Theileria ovis Turkey \\
KX273858.1 Theileria ovis Iran \\
KY283961.1 Theileria ovis Turkey \\
KT851428.1 Theileria ovis Turkey \\
KU342704.1 Theileria ovis Turkey \\
HM241892.1 Theileria ovis Turkey
\end{tabular}

Source: Kumar, S., Stecher, G. \& Tamura, K., 2016, 'MEGA7: molecular evolutionary genetics analysis version 7.0 for bigger datasets', Molecular biology and evolution 33(7), 1870-1874. FIGURE 3: In phylogenetic tree analysis of Theileria ovis based on $18 \mathrm{~S}$ ribosomal ribonucleic acid gene, the tree was constructed with maximum likelihood method based on Jukes-Cantor model, with bootstrap values (expressed as percentages of 1000 replications) superimposed at branching points. The sequences produced in this study are shown with bullet points. The evolutionary distances were computed using the $p$-distance method. Theileria luwenshuni was used as an out-group. higher infection rate in small ruminants, whereby Ringo et al. (2018) reported an overall infection of $19.8 \%$ and Berggoetz et al. (2014) reported an overall infection of $10.9 \%$. Theileria ovis known to be an agent of benign ovine and caprine theileriosis which has little economic importance (Mtshali et al. 2015) was identified in 30\% of sheep and none of the goats in this study. It was suggested that there are two possible reasons for the higher prevalence of TBPs in sheep as compared to goats: firstly, detection of ticks can be hampered by too much hair, which covers the sheep, resulting in persistence and low awareness of TBPs in sheep. Secondly, differences in natural resistance against TBPs among sheep and goats could influence the prevalence of the parasites (Aydin, Aktas \& Dumanli 2015, Gebrekidan et al. 2014; Rjeibi et al. 2014). Although the pathogen is less pathogenic, it cannot be completely neglected.

The phylogenetic tree of $18 \mathrm{~S}$ rRNA gene sequences constructed in the present study revealed that $T$. ovis from this study was placed in the same clade with most of the T. ovis sequences in this tree.

The absence of ovine Babesia sp. in this study is similar to previous reports by Aktas, Altay and Dumanli (2007) and Ringo et al. (2018) who could not detect ovine Babesia sp. in Turkey and South Africa, respectively. Similar results were also reported in Tunisia where B. motasi was not detected (Rjeibi et al. 2016). B. ovis is considered to be one of the most important TBPs in small ruminants and its absence could also be an indication that the pathogen is not common in the study area. From documented literature, B. ovis has only been documented in northern African countries including Algeria and Tunisia (Aouadi et al. 2017; Rjeibi et al. 2014).

Babesia bigemina and $B$. bovis are the two economically significant species infecting cattle in southern Africa, and they have shown to be present in all provinces of South Africa (Bock et al. 2004; Mtshali \& Mtshali 2013). Generally, the occurrence of both B. bigemina and B. bovis in the study area could be because of the presence and distribution of their tick vectors (Mtshali \& Mtshali 2013). In South Africa, the only vector of B. bovis is known to be Rhipicephalus (Boophilus) microplus, in contrast $B$. bigemina is transmitted by three tick vectors: R. (B) microplus, Rhipicephalus (Boophilus) decoloratus and Rhipicephalus evertsi evertsi (De Vos et al. 1994; Mtshali \&

TABLE 5: Evolutionary divergence of Theileria ovis representing 439 base pair region and expressed as pairwise distance ( $p$-distance) (bottom left) and standard error (top right).

\begin{tabular}{|c|c|c|c|c|c|c|c|c|c|}
\hline Accession number and Origin & 1 & 2 & 3 & 4 & 5 & 6 & 7 & 8 & 9 \\
\hline 1. MK643268.1 South Africa & - & 0.000 & 0.007 & 0.007 & 0.004 & 0.004 & 0.013 & 0.010 & 0.000 \\
\hline 2. MK643269.1 South Africa & 0.000 & - & 0.008 & 0.009 & 0.006 & 0.006 & 0.013 & 0.010 & 0.000 \\
\hline 3. HM241892.1 Turkey & 0.012 & 0.019 & - & 0.007 & 0.004 & 0.005 & 0.014 & 0.012 & 0.006 \\
\hline 4. MF033367.1 South Africa & 0.015 & 0.023 & 0.019 & - & 0.004 & 0.005 & 0.014 & 0.013 & 0.007 \\
\hline 5. MG203886.1 South Africa & 0.004 & 0.011 & 0.006 & 0.012 & - & 0.003 & 0.013 & 0.010 & 0.000 \\
\hline 6. MG203885.1 South Africa & 0.004 & 0.011 & 0.009 & 0.015 & 0.004 & - & 0.013 & 0.010 & 0.000 \\
\hline 8. JN412658.1 Iran & 0.027 & 0.028 & 0.036 & 0.041 & 0.027 & 0.027 & 0.041 & - & 0.010 \\
\hline 9. KY494648.1 Egypt & 0.000 & 0.000 & 0.008 & 0.013 & 0.000 & 0.000 & 0.044 & 0.027 & - \\
\hline
\end{tabular}

Source: Kumar, S., Stecher, G. \& Tamura, K., 2016, 'MEGA7: molecular evolutionary genetics analysis version 7.0 for bigger datasets', Molecular biology and evolution 33(7), $1870-1874$. 
Mtshali 2013). Uncontrolled movement of cattle that usually occurs within the province could also be one of the factors for the prevalence of bovine Babesia sp. in all municipalities sampled.

From the phylogenetic tree constructed, it is clear that our isolates showed a close relationship with B. bovis strains from South Africa, Brazil and China. The conservation of nucleotide diversity observed among the $R A P-1$ sequences has also been observed by Mtshali et al. (2013) and Ramos et al. (2012) in South Africa and Brazil, respectively. However, the isolates from this study formed a monophyletic grouping that is very distinct from that of other published B. bovis strains. According to Mtshali et al. (2013), this indicates the presence of micro-heterogeneities between the $R A P-1$ sequences within $B$. bovis strains. It is also important to note that the South African sequence KC894394 was obtained from samples collected in Mpumalanga province (Mtshali \& Mtshali 2013), hence the lack of 100\% identity to those generated in the current study.

With regard to the analysis of SpeI-AvaI restriction fragment sequence of $B$. bigemina isolates, the highest nucleotide identity was $89.0 \%$. It was recently discovered that the SpeIAvaI nested PCR assay specific for the detection of B. bigemina DNA also amplified a homologous fragment derived from Babesia ovata (Sivakimar et al. 2012). Nevertheless, this may not be the case in the present study because the presence of B. ovata has not yet been reported in the country's cattle (Mtshali et al. 2013; Yoshinari et al. 2013). To date, only five countries (Japan, Korea, China, Mongolia and Thailand) have reported the occurrence of B. ovata in cattle (Suh 1987; Sivakumar et al. 2012; Yoshinari et al. 2013).

Theileria parva is considered as the most significant theilerial species in sub-Saharan Africa and known to cause widespread morbidity and mortality in endemic areas. The absence of T. parva in the present study is comparable to results from a recent study in some parts of Nigeria where a $0,0 \%$ prevalence of the pathogen was reported (Okorafor \& Nzeako 2014). However, results of this study were not comparable to a study by Yusufmia et al. (2010) who reported a T. parva prevalence of $6.7 \%$ in cattle from South Africa. However, observations of the current study were not really surprising as it is known that Corridor disease is mainly restricted to buffaloes in South Africa because of strict preventative measures of the government that aim to ensure that the parasite is not introduced to cattle (Yusufmia et al. 2010). The specimens from this study were also obtained from apparently healthy cattle. In addition, South Africa is considered free of T. parva, except in designated Corridor disease-infected areas such as the Kruger National Park and Hluhluwe-iMfolozi Park that contain various wildlife species.

Animal trypanosomiasis acts as a serious impediment to animal husbandry in all tsetse fly infested regions of
sub-Saharan Africa (Nimpaye et al. 2011). In the present study, $18.3 \%$ of cattle showed the presence of Trypanosoma DNA in their blood. Uilenberg (1998), Van den Bossche et al. (2006) and Mamabolo et al. (2009) documented that tsetse fly vectors prefer cattle as their hosts as compared to other animals. The presence of Trypanosoma sp. in cattle is an indication that the cattle from uMkhanyakude district have encountered tsetse flies and its low prevalence may be attributed to the low sample size. These findings agree with a previous study by Mamabolo et al. (2009) who reported a Trypanosoma sp. prevalence of $18.4 \%$ in cattle in KZN. No Trypanosoma DNA was detected from goats, sheep and dogs, respectively. The absence of Trypanosoma in sheep and goats may be because of several factors such as the low tsetse feeding activity related to their small size and anti-feeding behaviour such as leg kicks and stamping, tail and ear flicks, head movement and skin rippling. According to Kniepert (1981), in communal grazing area, they attack cattle and leave most of the small ruminants uninfected. Canine African Trypanosomiasis (CAT) is seldomly reported (Gow, Simpson \& Picozzi 2007; Keck et al. 2009). Recently, Lisulo et al. (2014) reported on the occurrence of CAT in Zambian dogs. To date, in South Africa, only two cases have been reported, the first case was documented by Gow et al. (2007) where a 6-year-old dog was infected with $T$. congolense and Matjila et al. (2008) reported a case of T. congolense in a dog sample from the northern parts of KZN. Generally, CAT caused by T. congolense is fatal, thus, it would not be easy to find dogs which are carriers.

Ehrlichiosis is considered one of the most economically significant infectious diseases affecting small ruminants in tropical and subtropical regions (Ringo et al. 2018). The prevalence $(40.8 \%)$ of E. canis in the blood samples of dogs from the present study is higher than the prevalence of $19 \%$ for E. canis that was reported by Mtshali et al. (2017) from $R$. sanguineus ticks in South Africa. Other studies have reported seroprevalence of $42 \%, 34 \%$ and $53.8 \%$ for E. canis from dogs in South Africa, Zimbabwe and Namibia, respectively (Kelly, Eoghain \& Raoult 2004; Manyarara et al. 2015; Pretorius \& Kelly 1998). It is worth noting that the sampled dogs came from a low income area of KZN where there is a lack of access to effective tick control that could have contributed to the high prevalence.

Canine Babesia sp. and Hepatozoon sp. are causative agents of important tick-borne protozoal diseases of dogs. Despite the fact that dogs are increasing in numbers because of their different purposes in the country, less attention has been given to them by researchers as compared to other animals (Abdel-Rhman, Hegazy \& Al-Gaabary 2015). Although none of the domestic dogs in our study were positive for Babesia, the infection is known to be common in domestic dogs in South Africa with a prevalence of approximately $10 \%$ and a low prevalence has also been reported in Lusaka, Zambia (Collet 2000; Nalubamba et al. 2011). Failure to detect Babesia sp. in domestic dogs sampled in this study could be because the sampled animals have little or no 
contact with wild dogs including the black-backed jackal (Canis mesomelas), a known natural host of B. rossi (Penzhorn et al. 2017), or vectors, or the prevalence was too low to detect with our sample size. At present, in South Africa, $B$. vogelli has only been detected from the Free State and Onderstepoort Veterinary Academic Hospital, which is an indication that Babesia vogeli infection is not as widely spread as B. rossi in South Africa (Matjila et al. 2004, 2008). The absence of $H$. canis in this study is in agreement with studies by Criado-Fornelio et al. (2003) and Matjila et al. (2008) who could not detect this pathogen in domestic dogs from Europe and South Africa, respectively. H. canis has been reported from South African domestic dogs but only in wildlife. As $H$. canis is transmitted by ingestion of ticks, its absence in domestic dogs may be attributed to the fact that domestic dogs do not feed on live prey which reduce the probability of ingesting infected ticks with their prey (Baneth, Samish \& Shkap 2007). The parasite also seems to be present in high numbers in reticuloendothelial cells, so blood samples are unlikely to harbour-infected cells (Conceição-Silva et al. 1988).

In conclusion, the findings of this study have expanded our knowledge on the prevalence and phylogenetic similarity between protozoan parasites and Ehrlichia isolates of South African origin. To date, this is the first study to detect T. gondii infections in cattle using conventional PCR in South Africa.

\section{Acknowledgements}

The authors acknowledge the generous cooperation of local farmers who participated in this study and the kind cooperation of the veterinarians who helped during the collection of the blood samples.

\section{Competing interests}

The authors declare that they have no financial or personal relationships that may have inappropriately influenced them in writing this article.

\section{Authors' contributions}

O.M.M.T. and N.J.S.M. conceptualised the project. O.M.T supplied the samples. L.S.M. performed the laboratory procedures, analysed the data and drafted the manuscript. O.M.M.T., O.M.T. and N.J.S.M. reviewed the manuscript.

\section{Funding information}

The first author was sponsored by the National Research Foundation (NRF) of South Africa Scarce Skills Scholarship (Grant number: 114319). This work was made possible by the NRF Competitive Program for Rated Researchers grant (CPRR160429163437, grant 105979) made available to N.J.S.M.

\section{Data availability statement}

All new sequences are available on National Center for Biotechnology Information (NCBI) GenBank (MK643268.1 and MK643269.1).

\section{Disclaimer}

The views and opinions expressed in this article are those of the authors and do not necessarily reflect the official policy or position of affiliated agency of the authors.

\section{References}

Abdel-Rhman, A.A., Hegazy, Y.M. \& Al-Gaabary, M.H., 2015, 'Canine babesiosis in an endemic area of the Middle East: Causative agent identification, prevalence estimation and risk factors determination', Alexandria Journal for Veterinary Sciences 47(1), 104-112. https://doi.org/10.5455/ajvs.202612

Ademola, I.O. \& Onyiche, T.E., 2013, 'Haemoparasites and haematological parameters of slaughtered Ruminants and pigs at Bodija Abattoir, Ibadan, Nigeria', African Journal of Biomedical Research 16(2), 101-105.

Aguiar, D.M., Saito, T.B., Hagiwara, M.K., Machado, R.Z. \& Labruna, M.B., 2007 'Serological diagnosis of canine monocytic ehrlichiosis with Brazilian antigen of Ehrlichia canis', Ciência Rural 37(3), 796-802. https://doi.org/10.1590/S010384782007000300030

Aktas, M., Altay, K. \& Dumanli, N., 2007, 'Determination of prevalence and risk factors for infection with Babesia ovis in small ruminants from Turkey by polymerase chain reaction', Parasitology Research 100(4), 797-802. https://doi.org/10.1007/ s00436-006-0345-2

Aouadi, A., Leulmi, H., Boucheikhchoukh, M., Benakhla, A., Raoult, D. \& Parola, P., 2017, 'Molecular evidence of tick-borne hemoprotozoan-parasites (Theileria ovis and Babesia ovis) and bacteria in ticks and blood from small ruminants in Northern Algeria', Comparative Immunology, Microbiology and Infectious Diseases 50, 34-39. https://doi.org/10.1016/j.cimid.2016.11.008

Aydin, M.F., Aktas, M. \& Dumanli, N., 2015, 'Molecular identification of Theileria and Babesia in ticks collected from sheep and goats in the Black Sea region of Turkey', Parasitology Research 114(1), 65-69. https://doi.org/10.1007/s00436-014-4160-x

Baneth, G., Samish, M. \& Shkap, V., 2007, 'Life cycle of Hepatozoon canis (Apicomplexa: Adeleorina: Hepatozoidae) in the tick Rhipicephalus sanguineus and domestic dog (Canis familiaris)', Journal of Parasitology 93, 283-299. https://doi.org/10.1645/ GE-494R.1

Berggoetz, M., Schmid, M., Ston, D., Wyss, V., Chevillon, C., Pretorius, A.M. et al., 2014, 'Tick-borne pathogens in the blood of wild and domestic ungulates in South Africa: Interplay of game and livestock', Ticks and Tick-borne Diseases 5(2), 166-175. https://doi.org/10.1016/j.ttbdis.2013.10.007

Bock, R., Jackson, L., De Vos, A. \& Jorgensen, W., 2004, 'Babesiosis of cattle', Parasitology 129(1), 247-269. https://doi.org/10.1017/S0031182004005190

Bowie, W.R., King, A.S., Werker, D.H., Isaac-Renton, J.L., Bell, A., Eng, S.B. et al., 1997, 'Outbreak of toxoplasmosis associated with municipal drinking water', The Lancet 350(9072), 173-177. https://doi.org/10.1016/S0140-6736(96)11105-3

Burg, J.L., Grover, C.M., Pouletty, P. \& Boothroyd, J.C., 1989, 'Direct and sensitive detection of pathogenic protozoan, Toxoplasma gondii by polymerase chain reaction', Journal of Clinical Microbiology 27(8), 1787-1792. https://doi. org/10.1128/JCM.27.8.1787-1792.1989

Collett, M.G., 2000, 'Survey of canine babesiosis in South Africa', Journal of the South African Veterinary Association 71(3), 180-186. https://doi.org/10.4102/jsava. v71i3.710

Connor, R.J. \& Van den Bossche, P., 2004, 'African animal trypanosomes', in J.A.W Coetzer \& R.C. Tustin (eds.), Infectious diseases of livestock, 2nd edn., pp. 251-296, Oxford University Press Southern Africa, Cape Town.

Criado-Fornelio, A., Martinez-Marcos, A., Buling-Sarana, A. \& Barba-Carretero, J.C., 2003, 'Molecular studies on Babesia, Theileria and Hepatozoon in southern Europe: Part II. Phylogenetic analysis and evolutionary history', Veterinary Parasitology 114(3), 173-194. https://doi.org/10.1016/S0304-4017(03)00141-9

Desquesnes, M. \& Davila, A.M.R., 2002, 'Applications of PCR-based tools for detection and identification of animal trypanosomes: A review and perspectives', Veterinary Parasitology 109(3-4), 213-231. https://doi.org/10.1016/S0304-4017(02)00270-4

De Vos, A.J., Potgieter, F.T., De Waal, D.T. \& Van Heerden, J., 1994, Babesioses. Infectious diseases of livestock with special reference to southern Africa, pp. 278-308, Oxford University Press, Oxford.

Duarte, S.C., Linhares, G.F.C., Romanowsky, T.N., Da Silveira Neto, O.J. \& Borges, L.M.F., 2008, 'Assessment of primers designed for the subspecies-specific discrimination among Babesia canis canis, Babesia canis vogeli and Babesia canis rossi by PCR assay', Veterinary Parasitology 152(1-2), 16-20. https://doi. org/10.1016/j.vetpar.2007.12.013

Duranni et al. 2011, 'Prevalence of ovine Theileria species in district Lahore, Pakistan', Pakistan Journal of Zoology 43(1), 57-60.

Ewing, S.A. \& Panciera, R.J., 2003, 'American canine hepatozoonosis', Clinical Microbiology Reviews 16(4), 688-697. https://doi.org/10.1128/CMR.16.4.688697.2003 
Gebrekidan, H., Hailu, A., Kassahun, A., Rohoušová, I., Maia, C., Talmi-Frank, D. et al., 2014, 'Theileria infection in domestic ruminants in northern Ethiopia', Veterinary Parasitology 200(1-2), 31-38.

Gebremedhin, E.Z., Abdurahaman, M., Hadush, T. \& Tessema, T.S., 2014 'Seroprevalence and risk factors of Toxoplasma gondii infection in sheep and goats slaughtered for human consumption in Central Ethiopia', BMC Research Notes 7, 696. https://doi.org/10.1016/j.vetpar.2013.11.017

Gharbi, M., Zribi, L., Jedidi, M., Chakkhari, H., Hamdi, S., R'hayem, S. et al., 2013 , 'Prevalence infection of Toxoplasma gondii in Tunisian sheep', Bulletin de la Société de Pathologie Exotique 106(3), 184-187. https://doi.org/10.1007/s13149013-0290-4

Gondim, L.F., Kohayagawa, A., Alencar, N.X., Biondo, A.W., Takahira, R.K. \& Franco, S.R., 1998, 'Canine hepatozoonosis in Brazil: Description of eight naturally occurring cases', Veterinary Parasitology 74(2-4), 319-323. https://doi. org/10.1016/S0304-4017(96)01120-X

Gow, A.G., Simpson, J.W. \& Picozzi, K., 2007, 'First report of canine African trypanosomosis in the UK', Journal of Small Animal Practice 48(11), 658-661. https://doi.org/10.1111/j.1748-5827.2007.00423.x

Howe, D.K. \& Sibley, L.D., 1995, 'Toxoplasma gondii comprises three clonal lineages: Correlation of parasite genotype with human disease', Journal of Infectious Disease 172(6), 1561-1566. https://doi.org/10.1093/infdis/172.6.1561

Ijaz, M., Rehman, A., Ali, M.M., Umair, M., Khalid, S., Mehmood, K. et al., 2013 'Clinico-epidemiology and therapeutical trials on babesiosis in sheep and goats in Lahore, Pakistan', The Journal of Animal and Plant Sciences 23(2), goats in
$666-669$.

Jacobson, L.S., 2006, 'The South African form of severe and complicated canine babesiosis: Clinical advances 1994-2004', Veterinary Parasitology 138(1-2), 126-139. https://doi.org/10.1016/j.vetpar.2006.01.047

Joshua, R.A. \& Akinwumi, K.A., 2003, 'Prevalence of antibodies to Toxoplasma gondii in four breeds of cattle at Ibadan, Nigeria', Tropical Veterinarian 21(3), 134-137. https://doi.org/10.4314/tv.v21i3.4533

Keck, N., Herder, S., Kaba, D., Solano, P., Gomez, J., Cuny, G. et al., 2009, 'Epidemiological study of canine trypanosomosis in an urban area of Ivory Coast', Parasite 16(4), 305-308. https://doi.org/10.1051/parasite/2009164305

Kelly, P.J., Eoghain, G.N. \& Raoult, D., 2004, 'Antibodies reactive with Bartonella henselae and Ehrlichia canis in dogs from the communal lands of Zimbabwe', Journal of the South African Veterinary Association 75(3), 116-120. https://doi. org/10.4102/jsava.v75i3.465

Kniepert, F.W., 1981, 'Preference behaviour of female tabanids (Diptera, Tabanidae) on the host, Z. Angew', Entomology 91(1-5), 486-510. https://doi.org/10.1111/ j.1439-0418.1981.tb04508.x

Kumar, S., Stecher, G. \& Tamura, K., 2016, 'MEGA7: molecular evolutionary genetics analysis version 7.0 for bigger datasets', Molecular biology and evolution 33(7), analysis ver.

Lisulo, M., Sugimoto, C., Kajino, K., Hayashida, K., Mudenda, M., Moonga, L. et al., 2014, 'Determination of the prevalence of African trypanosome species in indigenous dogs of Mambwe district, eastern Zambia, by loop-mediated isothermal amplification', Parasites \& Vectors 7, 19. https://doi.org/10.1186/17563305-7-19

Luo, J. \& Yin, H., 1997, 'Theileriosis of sheep and goats in China', Tropical Animal Health and Production 29(Suppl 4), 8-10. https://doi.org/10.1007/ BF02632907

Mamabolo, M.V., Ntantiso, L., Latif, A. \& Majiwa, P.A.O., 2009, 'Natural infection of cattle and tsetse flies in South Africa with two genotypic groups of Trypanosoma congolense', Parasitology 136(4), 452-431. https://doi.org/ 10.1017/S0031182009005587

Mans, B.J., Pienaar, R., Latif, A.A. \& Potgieter, F.T., 2011, 'Diversity in the 18S SSU rRNA V4 hyper-variable region of Theileria spp. in Cape buffalo (Syncerus caffer) and cattle from southern Africa', Parasitology 138(6), 766-779. https://doi. org/10.1017/S0031182011000187

Manyarara, R., Tubbesing, U., Soni, M. \& Noden, B.H., 2015, 'Serodetection of Ehrlichia canis amongst dogs in central Namibia', Journal of the South
African Veterinary Association 86(1), 01-03. https://doi.org/10.4102/jsava. African Veteri
v86i1.1272

Matjila, P.T., Penzhorn, B.L., Bekker, C.P.J., Nijhof, A.M. \& Jongejan, F., 2004 'Confirmation of occurrence of Babesia canis vogeli in domestic dogs in South Africa', Veterinary Parasitology 122(2), 119-125. https://doi.org/10.1016/j. vetpar.2004.03.019

Matjila, P.T., Leisewitz, A.L., Jongejan, F. \& Penzhorn, B.L., 2008, 'Molecular detection of tick-borne protozoal and ehrlichial infections in domestic dogs in South Africa', Veterinary Parasitology 155(1-2), 152-157. https://doi.org/10.1016/j.vetpar. 2008.04.012

Mohammadi, S.M., Esmaeilnejad, B. \& Jalilzadeh-Amin, G., 2017, 'Molecular detection, infection rate and vectors of Theileria lestoquardi in goats from West Azerbaijan province, Iran', Veterinary Research Forum 8, 139-144.

Mtshali, K., Khumalo, Z.T., Nakao, R., Grab, D.J., Sugimoto, C. \& Thekisoe, O.M., 2015 'Molecular detection of zoonotic tick-borne pathogens from ticks collected from ruminants in four South African provinces', Journal of Veterinary Medical Science 77(12), 1573-1579. https://doi.org/10.1292/jvms.15-0170

Mtshali, K., Nakao, R., Sugimoto, C. \& Thekisoe, O., 2017, 'Occurrence of Coxiella burnetii, Ehrlichia canis, Rickettsia species and Anaplasma phagocytophilumlike bacterium in ticks collected from dogs and cats in South Africa', Journal of the South African Veterinary Association 88, 1-6. https://doi.org/10.4102/jsava. v88i0.1390

Mtshali, M.S. \& Mtshali, P.S., 2013, 'Molecular diagnosis and phylogenetic analysis of Babesia bigemina and Babesia bovis hemoparasites from cattle in South Africa', BMC Veterinary Research 9, 1-7. https://doi.org/10.1186/1746-6148-9-154
Mtshali, P.S., Tsotetsi, A.M., Thekisoe, M.M.O. \& Mtshali, M.S., 2013, 'Nested PCR detection and phylogenetic analysis of Babesia bovis and Babesia bigemina in cattle from peri-urban localities in Gauteng province, South Africa', Journal of cattle from peri-urban localities in Gauteng province, South Africa, Journal of
Veterinary Medical Science 76(1), 145-150. https://doi.org/10.1292/jvms.13-0197

Mundim, A.V., Mundim, M.J.S., Jensen, N.M.P. \& Araújo, S.F., 1994, 'Hepatozoon canis: Estudo retrospectivo de 22 casos de infec..o natural em c.es de Uberl.ndia, MG', Revista do Centro de Ciências Biomédicas da Universidade Federal de Uberlândia 10, 89-95.

Nalubamba, K.S., Hankanga, C., Mudenda, N.B. \& Masuku, M., 2011, 'The epidemiology of canine Babesia infections in Zambia', Preventive Veterinary Medicine 99(2-4), 240-244. https://doi.org/10.1016/j.prevetmed.2010.12.006

Nasiri, H., Forouzandeh, M., Rasaee, M.J. \& Rahbarizadeh, F., 2005, 'Modified salting out method: High-yield, high-quality genomic DNA extraction from whole blood using laundry detergent', Journal of Clinical Laboratory Analysis 19(6), 229-232. https://doi.org/10.1002/jcla.20083

Nimpaye, H., Njiokou, F., Njine, T., Njitchouang, G.R., Cuny, G., Herder, S. et al., 2011, "Trypanosoma vivax, T. congolense "forest type" and T. simiae: Prevalence in domestic animals of sleeping sickness foci of Cameroon', Parasite: Journal de la Société Française de Parasitologie 18(2), 171-179. https://doi.org/10.1051/ parasite/2011182171

OIE, 2013, 'Office of the International Epizootic Trypanosomosis- tsetse transmitted', In: OIE Terrestrial Manual, 1-11.

Okewole, E.A., 2007, 'Seroprevalence of antibodies to Toxoplasma gondii in some food and companion animals in the Southwestern Nigeria', Folia Veterinaria 51, 113-117.

Okorafor, U.P. \& Nzeako, S.O., 2014, 'Prevalence of haemoparasites of cattle from three abattoirs in Ibadan Metropolis, Oyostate, Nigeria', International Journal of Scientific Research in Environmental Sciences 2(7), 244-249. https://doi. org/10.12983/ijsres-2014-p0244-0249

Onyiche, T.E. \& Ademola, I.O., 2015, 'Seroprevalence of anti-Toxoplasma gondii antibodies in cattle and pigs in Ibadan, Nigeria', Journal of Parasitic Diseases 39(2), 309-314. https://doi.org/10.1007/s12639-013-0350-1

Peleg, O., Baneth, G., Eyal, O., Inbar, J. \& Harrus, S., 2010, 'Multiplex real-time qPCR for the detection of Ehrlichia canis and Babesia canis vogeli', Veterinary Parasitology 173(3-4), 292-299. https://doi.org/10.1016/j.vetpar.2010.06.039

Penzhorn, B.L., Vorster, I., Harrison-White, R.F. \& Oosthuizen, M.C., 2017, 'Blackbacked jackals (Canis mesolamus) are natural hosts of Babesia rossi, the virulent causative agent of canine babesiosis in sub-Saharan Africa', Parasites \& Vectors 10(1), 124.

Perry, B. \& Sones, K., 2007, 'Poverty reduction through animal health', Science 315(5810), 333-334. https://doi.org/10.1126/science.1138614

Pretorius, A.M. \& Kelly, P.J., 1998, 'Serological survey for antibodies reactive with Ehrlichia canis and E. chaffeensis in dogs from the Bloemfontein area, South Africa', Journal of the South African Veterinary Association 69(4), 126-128. https://doi.org/10.4102/jsava.v69i4.840

Ramos, C.A., Araújo, F.R., Alves, L.C., De Souza, I.I.F., Guedes, Jr. D.S. \& Soares, C.O. 2012 , 'Genetic conservation of potentially immunogenic proteins among Brazilian isolates of Babesia bovis', Veterinary Parasitology 187(3-4), 548-552. https://doi. org/10.1016/j.vetpar.2012.01.020

Ringo, A.E., Moumouni, P.F.A., Taioe, M., Jirapattharasate, C., Liu, M., Wang, G. et al., 2018, 'Molecular analysis of tick-borne protozoan and rickettsial pathogens in small ruminants from two South African provinces', Parasitology International 67(2), 144-149. https://doi.org/10.1016/j.parint.2017.11.002

Rjeibi, M.R., Darghouth, M.A., Rekik, M., Amor, B., Sassi, L. \& Gharbi, M., 2016, 'First molecular identification and genetic characterization of Theileria lestoquardi in sheep of the Maghreb region', Transboundary and Emerging Diseases 63(3), 278-284. https://doi.org/10.1111/tbed.12271

Rjeibi, M.R., Gharbi, M., Mhadhbi, M., Mabrouk, W., Ayari, B., Nasfi, I. et al., 2014, 'Prevalence of piroplasms in small ruminants in North-West Tunisia and the first genetic characterisation of Babesia ovis in Africa', Parasite 21(23), 9. https://doi. genetic characterisation of Babesic
org/10.1051/parasite/2014025

Shayan, P., Hooshmand, E. \& Rahbari, S., 2008, 'Biometrical and genetical characterization of large Babesia ovis in Iran', Parasitology Research 103(1), 217-221. https://doi.org/10.1007/s00436-008-0960-1

Sivakumar, T., Tagawa, M., Yoshinari, T., Ybañez, A.P., Igarashi, I., Ikehara, Y. et al., 2012 'PCR detection of Babesia ovata from cattle reared in Japan and clinical significance of co-infection with Theileria orientalis', Journal of Clinical Microbiology 50(6), 2111-2113. https://doi.org/10.1128/JCM.00220-12

Steverding, D., 2008, 'The history of African trypanosomiasis', Parasites \& Vectors 1(1), 3. https://doi.org/10.1186/1756-3305-1-3

Suh, M.D., 1987, 'Pure isolation and identification of Babesia ovata by morphological characteristics and complement fixation test in Korea', Korean Journal of Veterinary Research 27, 307-316.

Taques, I.I.G.G., Barbosa, T.R., De Cássia Martini, A., Pitchenin, L.C., Braga, Í.A., De Melo, A.L.T. et al., 2016, 'Molecular assessment of the transplacental transmission of Toxoplasma gondii, Neospora caninum, Brucella canis and Ehrlichia canis in dogs', Comparative Immunology, Microbiology and Infectious Diseases 49, 47-50. https://doi.org/10.1016/j.cimid.2016.09.002

Terkawi, M.A., Thekisoe, O.M., Katsande, C., Latif, A.A., Mans, B.J., Matthee, O. et al., 2011 , 'Serological survey of Babesia bovis and Babesia bigemina in cattle in South Africa', Veterinary Parasitology 182(2-4), 337-342. https://doi.org/10.1016/j. vetpar.2011.05.047

Torgerson, P.R., Devleesschauwer, B., Praet, N., Speybroeck, N., Willingham, A.L. Kasuga, F. et al., 2015, 'World Health Organization estimates of the global and regional disease burden of 11 foodborne parasitic diseases, 2010a data synthesis', PLOS Medicine 12(12), 1001920. https://doi.org/10.1371/journal. pmed.1001920 
Trail, J.C.M., Wissocq, N., d'leteren, G.D.M., Kakiese, O. \& Murray, M., 1994, 'Patterns of Trypanosoma vivax and T. congolense infection differ in young N'Dama cattle and their dams', Veterinary Parasitology 55(3), 175-183. https://doi. org/10.1016/0304-4017(94)00647-U

Uilenberg, G., 1998, A field guide for diagnosis, treatment and prevention of African animal trypanosomiasis, 2nd edn., Food and agriculture organization of the United State, Rome.

Uilenberg, G., 1999, 'Immunization against diseases caused by Theileria parva: A review', Tropical Medicine and International Health 4(9), 12-20. https://doi. org/10.1046/j.1365-3156.1999.00446.x

Van den Bossche, P., Esterhuizen, J., Nkuna, R., Matjila, T., Penzhorn, B., Geerts, S. et al., 2006, 'An update of the bovine trypanosomosis situation at the edge of Hluhluwe-iMfolozi Park, KwaZulu-Natal Province, South Africa, research communication', Onderstepoort Journal of Veterinary Research 73(1), 77-79. https://doi.org/10.4102/ojvr.v73i1.172

Vieira, R.F.D.C., Biondo, A.W., Guimarães, A.M.S., Santos, A.P.D., Santos, R.P.D., Dutra, L.H. et al., 2011, 'Ehrlichiosis in Brazil', Revista Brasileira de Parasitologia Veterinária 20(1), 01-12. https://doi.org/10.1590/\$1984-29612011000100002
Wellde, B.T., Reardon, M.J., Kovatch, R.M., Chumo, D.A., Williams, J.S., Boyce, W.L. et al., 1989, 'Experimental infection of cattle with Trypanosoma brucei rhodesiense', Annals of Tropical Medicine \& Parasitology 83(Suppl 1), 133-150. https://doi.org/10.1080/00034983.1989.11812418

Weny, G., Okwee-Acai, J., Okech, S.G., Tumwine, G., Ndyanabo, S., Abigaba, S. et al. 2017, 'Prevalence and risk factors associated with hemoparasites in cattle and goats at the Edge of Kibale National Park, Western Uganda', Journal of Parasitology 103(1), 69-74. https://doi.org/10.1645/16-33

Yoshinari, T., Sivakumar, T., Asada, M., Battsetseg, B., Huang, X., Lan, D.T.B. et al., 2013 'A PCR based survey of Babesia ovata in cattle from various Asian, African and South American countries', Journal of Veterinary Medical Science 75(2), 211-214. https://doi.org/10.1292/jvms.12-0329

Yusufmia, S.B.A.S., Collins, N.E., Nkuna, R., Troskie, M., Van den Bossche, P. \& Penzhorn, B.L., 2010, 'Occurrence of Theileria parva and other haemoprotozoa in cattle at the edge of Hluhluwe-iMfolozi Park, KwaZulu-Natal, South Africa', Journal of the South African Veterinary Association 81(1), 45-49. https://doi.org/10.4102/ jsava.v81i1.95 


\section{Appendix 1}

\begin{tabular}{|c|c|c|c|c|c|c|c|}
\hline \multicolumn{2}{|c|}{$\begin{array}{l}\text { Score } \\
110 \text { bits(121) }\end{array}$} & $\begin{array}{l}\text { Expect } \\
2 \mathrm{e}-20\end{array}$ & \multicolumn{2}{|c|}{$\begin{array}{l}\text { Identities } \\
74 / 83(89 \%)\end{array}$} & $\begin{array}{l}\text { Gaps } \\
0 / 83(0 \%)\end{array}$ & \multicolumn{2}{|l|}{$\begin{array}{l}\text { Strand } \\
\text { Plus/Plus }\end{array}$} \\
\hline $\begin{array}{l}\text { Query } \\
\text { Sbjet }\end{array}$ & $\begin{array}{l}12 \\
2531752\end{array}$ & \multicolumn{5}{|c|}{ 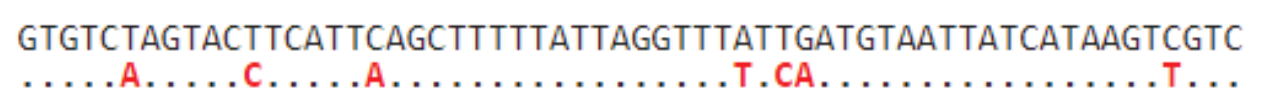 } & $\begin{array}{l}71 \\
2531811\end{array}$ \\
\hline $\begin{array}{l}\text { Query } \\
\text { Sbjet }\end{array}$ & $\begin{array}{l}72 \\
2531812\end{array}$ & \multicolumn{2}{|c|}{$\begin{array}{l}\text { АСTTCGTCTTCGTTTTTCACCGC } \\
\ldots \ldots \text { A.T. } \ldots \ldots \ldots \ldots \ldots\end{array}$} & & & & \\
\hline
\end{tabular}

Source: Figure constructed by authors using NCBI-BLASTn online program (https://blast.ncbi.nlm.nih.gov/Blast.cgi).

Sbjct, subject.

FIGURE 1-A1: BLASTn result showing the alignment of B. bigemina isolate (United Kingdom - LK391707.1) and one sequence (B. bigemina KZN-Hlabisa isolate) obtained from the study. Nucleotide identity is represented by dots.

\begin{tabular}{|c|c|c|c|c|c|c|}
\hline $\begin{array}{l}\text { Score } \\
352 \text { bi }\end{array}$ & $s(390)$ & $\begin{array}{l}\text { Expect } \\
2 \mathrm{e}-93\end{array}$ & $\begin{array}{l}\text { Identities } \\
195 / 195(100 \%)\end{array}$ & $\begin{array}{l}\text { Gaps } \\
0 / 195(0 \%)\end{array}$ & \multicolumn{2}{|c|}{$\begin{array}{l}\text { Strand } \\
\text { Plus/Minus }\end{array}$} \\
\hline $\begin{array}{l}\text { Query } \\
\text { Sbjet }\end{array}$ & $\begin{array}{l}1 \\
225\end{array}$ & \multicolumn{4}{|c|}{ 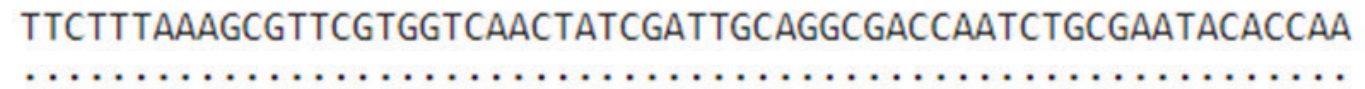 } & $\begin{array}{l}60 \\
166\end{array}$ \\
\hline $\begin{array}{l}\text { Query } \\
\text { Sbjet }\end{array}$ & $\begin{array}{l}61 \\
165\end{array}$ & \multicolumn{4}{|c|}{$\begin{array}{l}\text { AGTTGCACAGATACTCATGAATTTCACTTTTCGCCAGCAGAGGGGAGCTCGTCAGTGACT } \\
\ldots \ldots \ldots \ldots \ldots \ldots \ldots \ldots \ldots \ldots \ldots \ldots \ldots \ldots \ldots \ldots \ldots \ldots \ldots \ldots \ldots \ldots \ldots \ldots \ldots \ldots \ldots \ldots\end{array}$} & $\begin{array}{l}120 \\
106\end{array}$ \\
\hline $\begin{array}{l}\text { Query } \\
\text { Sbjet }\end{array}$ & $\begin{array}{l}121 \\
105\end{array}$ & \multicolumn{4}{|c|}{ 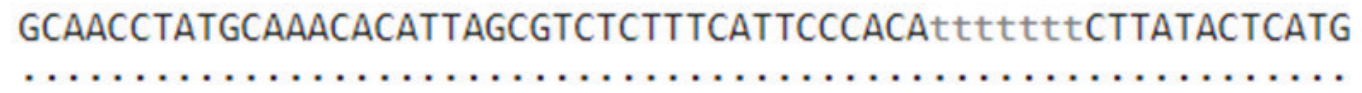 } & $\begin{array}{l}180 \\
46\end{array}$ \\
\hline $\begin{array}{l}\text { Query } \\
\text { Sbjet }\end{array}$ & $\begin{array}{l}181 \\
45\end{array}$ & $\begin{array}{l}\text { AACGGATGCAGTTCC } \\
\cdots \cdots \cdots \cdots \cdots \cdots\end{array}$ & $\begin{array}{l}195 \\
31\end{array}$ & & & \\
\hline
\end{tabular}

Source: Figure constructed by authors using NCBI-BLASTn online program (https://blast.ncbi.nlm.nih.gov/Blast.cgi).

Sbjct, subject.

FIGURE 2-A1: BLASTn result showing the alignment of $T$. gondii isolate (China -MK521884.1) and one sequence (T. gondii KZN-Hlabisa isolate) obtained from the study. Nucleotide identity is represented by dots.

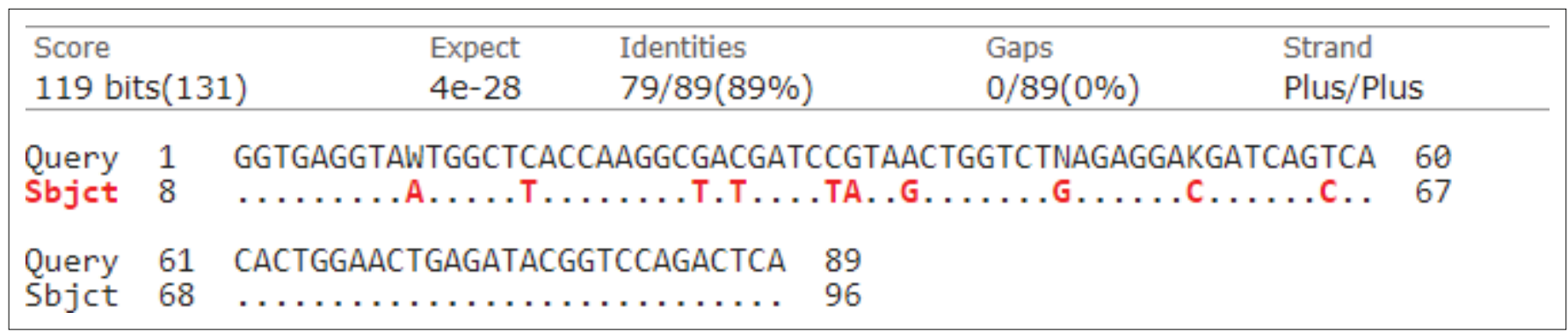

Source: Figure constructed by authors using NCBI-BLASTn online program (https://blast.ncbi.nlm.nih.gov/Blast.cgi).

Sbjct, subject.

FIGURE 3-A1: BLASTn result showing the alignment of E. canis isolate (Vietnam-MH686052.1) and one sequence (E. canis KZN-Hlabisa isolate) obtained from the study. Nucleotide identity is represented by dots. 